Neurosurg Focus 11 (2):Article 5, 2001, Click here to return to Table of Contents

\title{
Ibn Sina (Avicenna)
}

\author{
Historical vignette
}

\begin{abstract}
Asita S. Sarrafzadeh, M.D., Nuri Sarafian, Ph.D., Almut von Gladiss, Ph.D., Andreas W. Unterberg, M.D., Ph.D., And Wolfgang R. Lanksch, M.D., Ph.D.
\end{abstract}

\author{
Department of Neurosurgery, Charité Campus Virchow Medical Center, Humboldt University and \\ Museum of Islamic Art, Berlin, Germany
}

\begin{abstract}
Ibn Sina (often known by his last name in Latin, Avicenna; 980-1037 A.D.) was the most famous physician and philosopher of his time. His Canon of Medicine, one of the most famous books in the history of medicine, surveyed the entire medical knowledge available from ancient and Muslim sources and provided his own contributions. In this article the authors present a unique picture of the neurosurgical technique of Ibn Sina and briefly summarize his life and work.
\end{abstract}

\section{KEY WordS • Avicenna • Ibn Sina • historical article}

\section{HISTORICAL CASE}

\section{The Life of Ibn Sina}

Ibn Sina is widely known by his Latin name of Avicenna, although most references to him today have reverted to the correct version of Ibn Sina, in full Abu 'Ali alHusayn ibn 'Abd Allah Joyce ibn Sina. He was born in 980 in Afsana near Bukhara, now Usbekistan, and died in 1037 in Hamadan (now Iran). He was the most famous physician, philosopher, encyclopedist, mathematician, and astronomer of his time. ${ }^{1}$

A gifted child with an exceptional memory, by the age of $10 \mathrm{Ibn}$ Sina had become well versed in the study of the Qur'an and various sciences. He started studying philosophy by reading various Greek, Muslim, and other texts and learned logic and metaphysics under teachers whose knowledge he soon surpassed. Thereafter, until he reached the age of 18 years, he engaged in self education. He read avidly and mastered Islamic law, medicine, and finally metaphysics. At 17 years of age, he was able to treat and cure Nuh ibn Mansur (Nooh Ibn Mansoor), the King of Bukhhara, of an illness considered untreatable by all the well-known physicians. On his recovery, the King wished to reward Ibn Sina, but the young physician desired only permission to use the King's uniquely stocked library. This access to the rich, royal library of the Samanids - the first great native dynasty that arose in Iran after the Arab conquests-was particularly helpful in his intellectual development. By the time he was 21-years-old he was accomplished in all branches of formal learning and had already gained a wide reputation as an outstanding physician. His services were also sought as an administrator, and for a while he even entered governmental services as a clerk. Avicenna continued to practice as a physician and political administrator, in the courts of the various Iranian rulers, during the numerous successor states of Iran that emerged during the disintegration of the Abbasid authority. Later he moved to Rayy and then to Hamadan, where he wrote his famous book Al-Qanun fi al-Tibb. Here he treated Shams al-Dawlah, the King of Hamadan, for severe colic. From Hamadan, he moved to Isphahan, where he completed many of his monumental writings. Avicenna wrote 99 books, almost all in Arabic, the language of religious and scientific expression in the Muslim world at that time. Two of his works, the Daneshnameh-e-Alai (Encyclopedia of Philosophical Sciences) and a small treatise on the pulse, however, were written in Farsi, his native language. ${ }^{6}$ He also wrote about natural philosophy and astronomy, theology and metaphysics, medicine, psychology, music, mathematics, and physical sciences, and he is reportedly the author of Persian quatrains and short poems. ${ }^{1}$ Avicenna then wandered in different cities of Chorasan and then left for the court of the Buyid princes, who ruled central Iran, first going to Rayy (near modern Tehran) and then to Qazvin, where, as usual, he made his livelihood as a physician. In Rayy, which was a prosperous city in northern Persia, he treated and cured the king's melancholia, and he described these observations later in a text entitled "State of the Human Soul." 4,6 In these cities he found neither sufficient social and economic support nor the necessary peace and calm in which to continue his work. He went, therefore, to Hamadan in west-central Iran, where Shams ad-Dawlah, another Buyid prince, was the ruler. This journey marked the beginning of a new phase in Avicenna's life. He became court physician and enjoyed the favor of the ruler to the extent that twice he was appointed vizier. Here, as already mentioned, he treated the King of Hamadan for severe colic. As was the order of the day, he also suffered political reactions and intrigues and was forced into hiding for some time; at one time he was even imprisoned in the Festung Fardajan. 
From Hamadan, he moved to Isfahan and he completed many of his monumental writings about physics and metaphysics. Finally, he returned to Hamadan, where he died in 1037 of severe colic, a disease, ironically, he was able to treat so successfully in his patients. ${ }^{1,4,6}$

\section{The Canon of Medicine}

Ibn Sina was particularly noted for his contributions to the fields of medicine and Aristotelian philosophy. His two most important works are The Book of Healing and $A l$ Qanun, known as the Canon of Medicine in the West. ${ }^{4,9}$ The first is a scientific encyclopedia covering logic, natural sciences, psychology, geometry, astronomy, arithmetic, and music. The second (circa 1030 A.D.) is the one of the most famous books in the history of medicine (Fig. 1). In it he surveyed the entire medical knowledge available from ancient Christian-Latin and Muslim sources, and the book is enriched by the author's original contributions. The Canon became the standard of medical science and was on par with works of Hippocrates (460-377 B.C.) and Galen (129-199 A.D.) in all important libraries of European universities. The Canon of Medicine consists of five books. These classify systematically the available

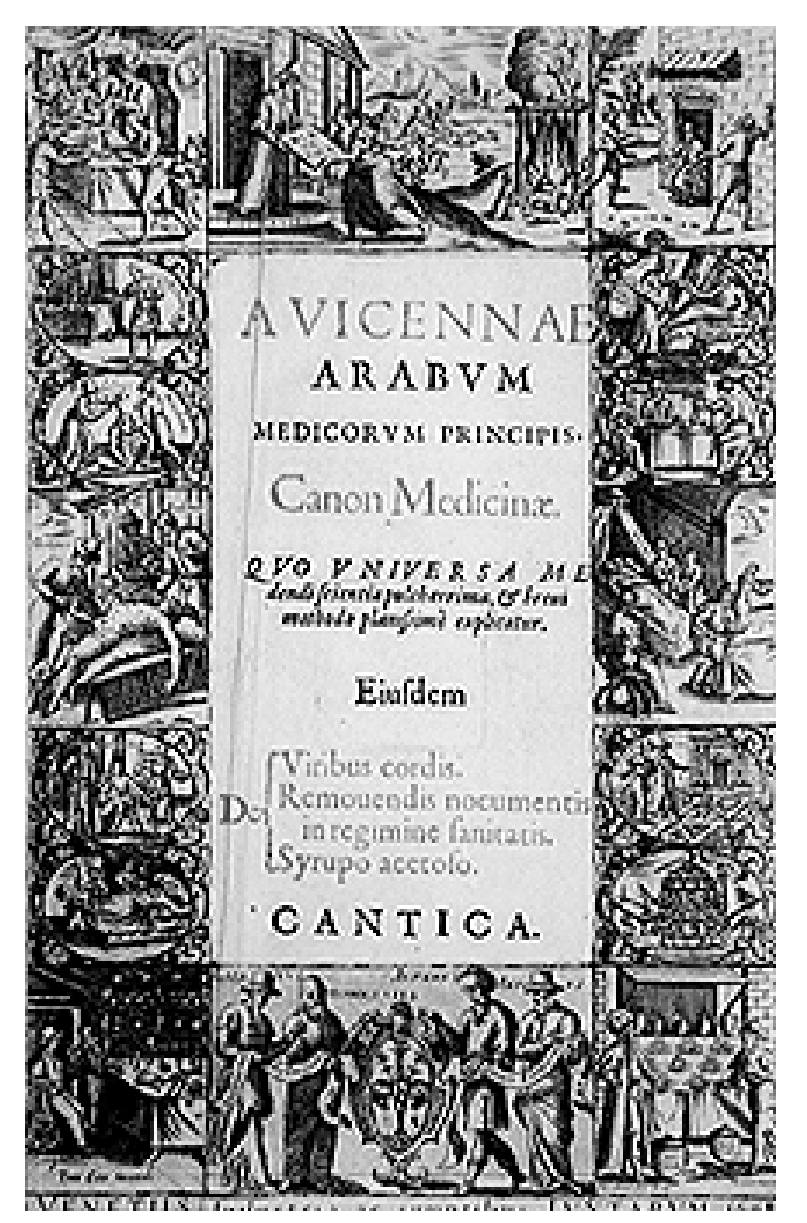

Fig. 1. Photograph showing the title page of an ancient edition of the Canon of Medicine (Venice, 1608), translated into Latin, which is available in the library of the Humboldt University, Berlin, Germany. knowledge of anatomy, physiology, and pharmacology (Books 1 and 2); the pathology describing the diseases of the internal organs and typical symptoms according to Galen's classification (Book 3); fever (Book 4); and materia medica (Book 5) (Fig. 2). ${ }^{2,9}$ In this last book Avicenna describes 760 drugs with instructions of preparation, and this became the most authentic materia medica of the era. In total the Canon of Medicine consists of approximately a million arabic words on 1000 pages, written in a completely systematic manner. ${ }^{2}$ Ibn Sina begins his Canon with the following words: "It is my heart's desire, to start off with speaking about the general and common principles of both parts of medicine, i.e., theory and practice." ${ }^{9}$ For medical students, Ibn Sina condensed the knowledge of the Canon of Medicine to 1326 verses (the "Urguza fi" ttibb"). The first translation into Latin was written in the 12th century by Gerhard von Cremona (1135-1187), and the first Hebrew version appeared around $1491 .{ }^{9}$ In the Arabic language the Canon of Medicine appeared in 1593 and is thought to be the second book ever printed in Arabic. The Canon gained widespread popularity only after the introduction of typography in the 15th and 16th centuries, but its impact throughout Europe remained steady until the end of the 18th century. Now, in only a few European libraries is the complete Canon of Medicine available (a 1482 edition in Paris, and a 1658 editions in Padova and Milano, Italy, and in Berlin). There is only one critical edition in a modern language (Russian), limiting an actual interpretation of this work. ${ }^{4}$

\section{Ibn Sina and Neurological Knowledge}

Ibn Sina's important original contributions include such advances as anatomy, gynecology, and pediatric health, and the recognition of the contagious nature of phthisis and tuberculosis; the distribution of diseases by water and soil; and the interaction between psychology and health. Of scientific methodology he wrote, "[An] experiment can only lead to a knowledge of the drug effect if the conditions are observed continuously in detail", which was a concept labeled by Alexander von Humboldt and Francis Bacon as "ratio and experimentum". ${ }^{9}$ Ibn Sina's contributions were not only theoretical. He was an excellent practicioner and surgeon who also treated the poor. ${ }^{1,6}$ In the Canon of Medicine he described various surgical procedures such as tracheotomy and repair of rectal fistulas. Unfortunately, because there is no known paper other than the Canon in which Avicenna's surgical procedures are described, the extent of his surgical practice remains unknown. His detailed anatomical knowledge, however, which was difficult to refine at that time because anatomical studies were forbidden for religious reasons, suggests a broad surgery-related experience.

Ibn Sina was a dedicated medical doctor, passing the day with the patients and writing mainly in the evening hours. He was well versed in intracranial anatomy and expanded on Galenic knowledge, dividing the brain into the medulla and cortex (translated by Gerhard of Cremona as "substantia medullaris" and "substantia velativa"). ${ }^{6} \mathrm{He}$ considered the third ventricle to be a conduit, not as a single ventricle, already using this term both for the brain and heart. He described a caudal communication with the infundibulum, termed the "al-Chamba" (or "caput rosae"). 


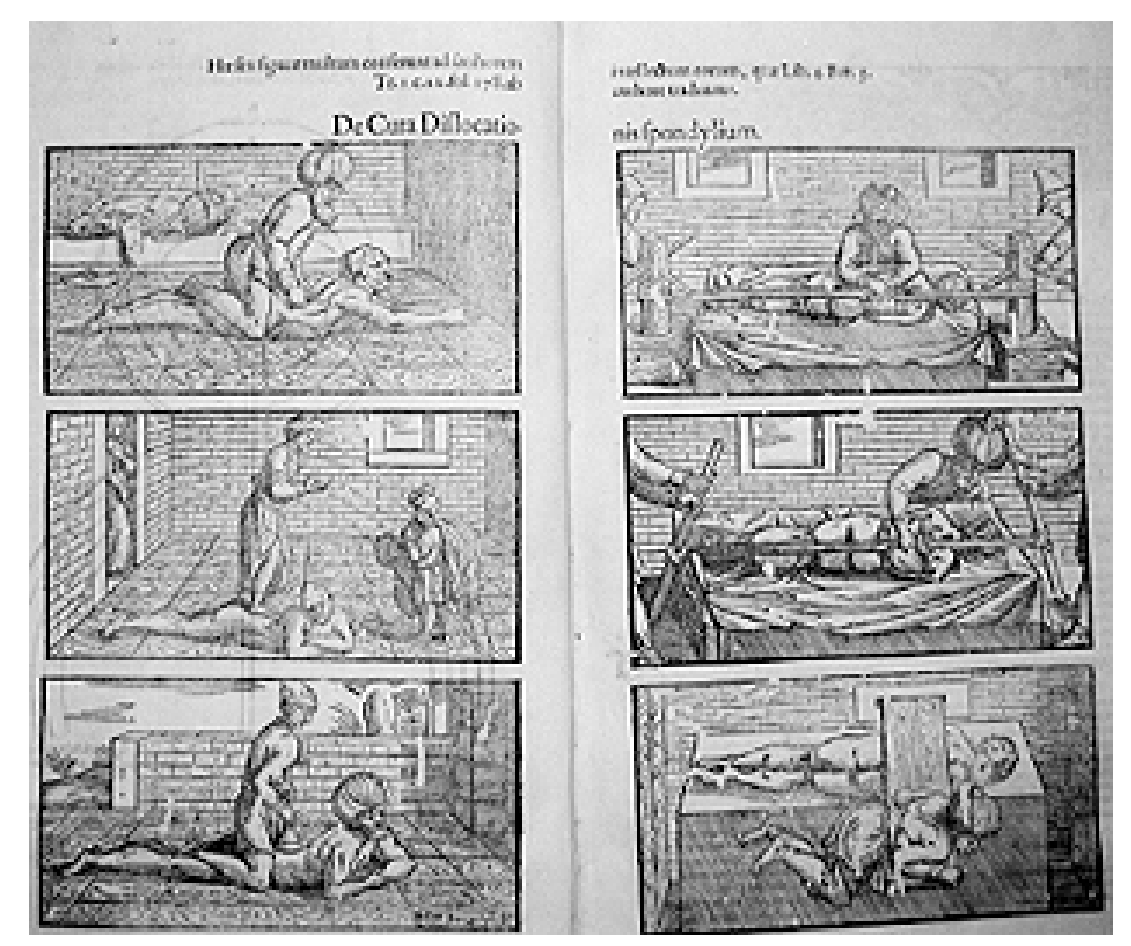

Fig. 2. A sequence of different treatment options for lumbosacral pain, described in Book 1 of the Canon of Medicine is pictured. Illustrations are taken from the 1608 Latin edition published in Venice.

The spinal cord ("nucha") he described poetically, "as a broad stream which flows smoothly out of the bubbling source of the brain." 10 Ibn Sina developed a "theory of the ventricles" in which he explained the physiology and meaning of the ventricles as a source of power, situated in the anterior part of the brain and related to perception and memory; this was later described in 1500 as "cell theory" by Hundt and others in terms as "camera phantastica, camera rationalis and camera memoria."

Ibn Sina was the first physician to describe and characterize meningitis as a disease $;{ }^{4}$ unfortunately, none of his detailed descriptions is available. After long studies during the night combined with the consumption of wine, he explained that his headache was a pain evoked by the presence of a toxic drug penetrating the membranes that surrounded his brain and causing brain swelling. According to Al Guzgani, his long-term student and biographer, the recommended treatment of choice was cooling of the head with large amounts of ice. ${ }^{4}$

\section{Ibn Sina and Neurosurgery}

That Ibn Sina was also a predecessor of modern intracranial surgery remains highly speculative. Archeological excavations have provided evidence that skull trephination was performed in pre-Hispanic Mexican and Incan cultures, ${ }^{8,12}$ presumably for ritualistic, prophylactic, and therapeutic reasons, in the latter cases with obvious evidence of trauma-induced fractures. The location of skull perforation was predominantly parietal and less often frontal and occipital. ${ }^{11}$ Approximately $90 \%$ of the trephinations showed evidence of healing, indicating that the individual had survived the procedure. The engravings in Fig. 3 provide some idea of how a neurosurgical proce- dure could have been performed during Ibn Sina's time. Engraved in copper, Ibn Sina is pictured performing a neurosurgical procedure, probably a burr-hole trephination, in a king; the operation is being conducted in a palace hall, which is characterized by the arcades of columns. On metal, the first scenes with figures were found in the 19th century. ${ }^{3}$ The composition and style of the work pictured in Fig. 3 are typical of the early 20th century. There is no known source in the literature in which Avicenna is described performing neurosurgical operations. Individuals were not portrayed for many centuries because of the Islamic tradition. Therefore, the illustration can only serve to represent our speculation as to how Ibn Sina might have performed surgery. Pictures of Ibn Sina are therefore extremely rare; the first were found in a late Persian book of paintings ${ }^{5}$ and are now available on various on-line web pages. ${ }^{67}$ They portray Ibn Sina as a person or as a teacher with his students. The existence of actual portrayals of Ibn Sina with patients, especially performing a neurosurgical procedure, are unknown or unpublished.

In our Fig. 3 lower, the head of the patient is fixed, and the operative instruments are spread out on a small table. At that time, opium was a common anesthetic agent and was possibly given for analgesia and sedation. In the background of the engraving are numerous spectators and different scenes in a palace hall surrounding Ibn Sina.

There are two epigraphs written in Farsi. The upper one translates into "surgery of a king by the famous philosopher Ibn Sina [one] thousand years ago" whereas the lower epigraph is a famous, often-cited poem: "Although my senses were searching the desert fatiguelessly; discovering nothing although finding a lot; my soul was illuminated by a thousand suns; but could never ever touch the 


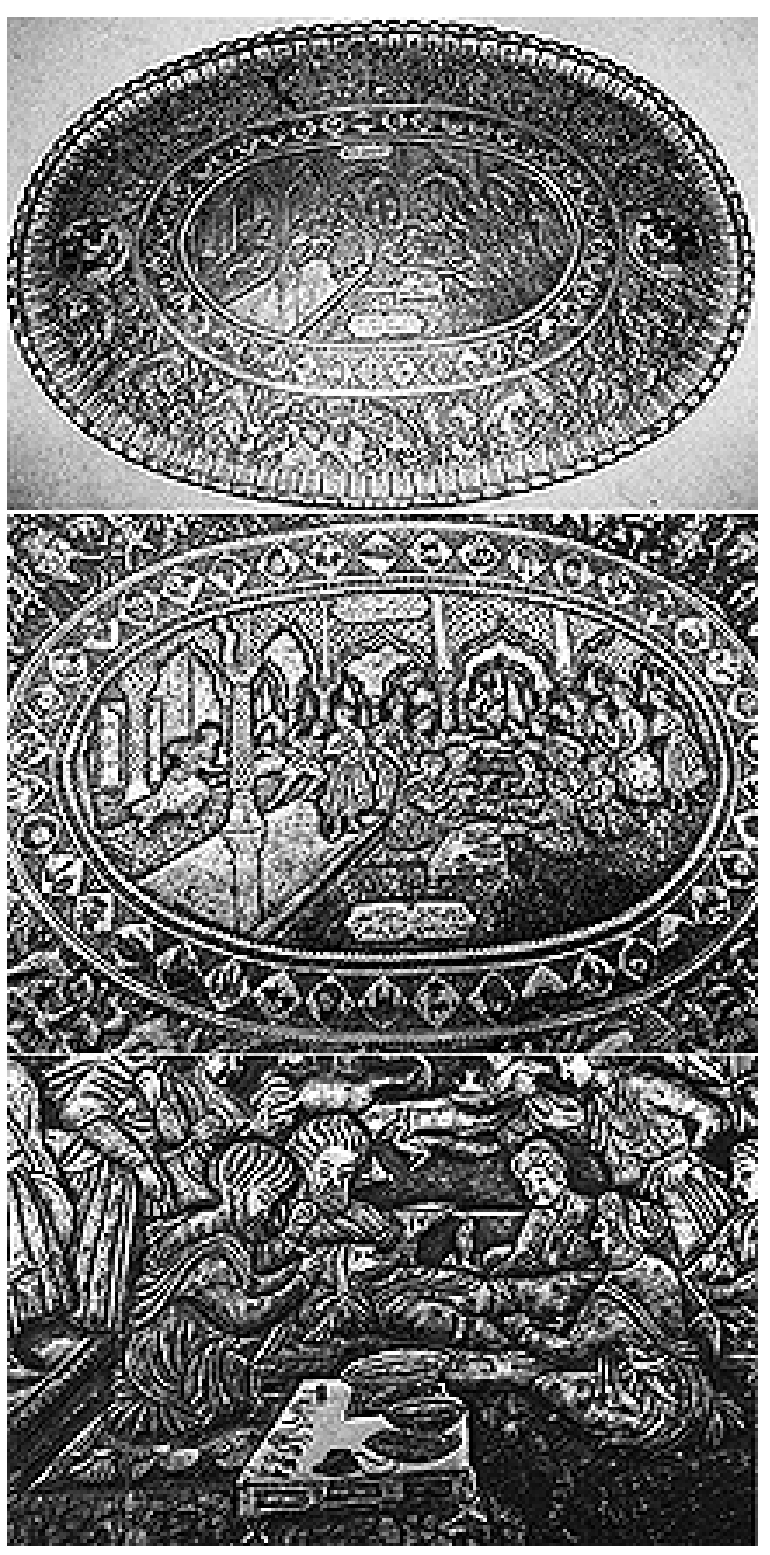

Fig. 3. Miniature work $(1.28 \times 98 \mathrm{~cm}$, oval $)$ engraved on copper. Upper: Photograph showing the entire engraving, in which Ibn Sina is performing a neurosurgical procedure, probably a burrhole trephination in a king. Center: In the background numerous spectators and different scenes in a palace hall surrounding Ibn Sina are shown in miniature. Lower: Details of the surgical procedure are depicted. The eyes of the patient are closed and his head is fixed; the surgical instruments can be observed on a small table in the foreground. The assistant is sitting to the left of Ibn Sina. Three men are holding both arms and legs of the patient.

perfection of a single atom. ${ }^{, 4,9}$ This poem can be found on a statue in Teheran of 1954 and is probably related to Ibn Sina's works on physics and astronomical observations. ${ }^{9}$ In these, he described the study of different forms of ener- gy, heat, light, and mechanics, as well as such concepts as force, vacuum, and infinity, and he hypothetized that if the perception of light is caused by the emission of some sort of particles by the luminous source, then the speed of light must be infinite. ${ }^{7}$

\section{CONCLUSIONS}

Ibn Sina, the most famous physician and philosopher of his time, summarized all of his medical knowledge in the Canon of Medicine. He is worth remembering as a teacher's teacher for generations of students. As with other great physicians of the premodern era, his investigations and expertise included study and treatment of the nervous system. It is our hope that the increasing availability of translations of the Canon of Medicine will expand awareness of his life and work.

\section{References}

1. Asimov M: The life and teachings of Ibn Sina. Indian J Hist Sci 21:220-243, 1986

2. Avicenna: Canon Medicinae. Berlin: Humboldt University Library of Historical Sciences, 1658

3. Brandenburg D: Islamic Miniature Painting in Medical Manuscripts. Basel: Editiones Roche, 1982

4. Brentjes B, Brentjes S: Ibn Sina (Avicenna), der fürstliche Meister aus Buchara. Leipzig: Teubner Verlagsgesellschaft, 1979, pp 78-100

5. Gluck J, Gluck SH (eds): A Survey of Persian Handicraft. A Pictoral Introduction of the Contemporary Folk Arts and Art Crafts of Modern Iran. Teheran: Bank Melli Iran, 1977

6. Nasr SH: Avicenna. Encyclopaedia Britannica Online. http:// members.eb.com/bol/topic?eu=11566 [Accessed 26 July 2001]

7. O'Connor JJ, Robertson EF: Abu Ali al-Husain ibn Abdallah ibn Sina (Avicenna). School of Mathematics and Statistics, University of St Andrews, Scotland Online. <http://www. history.mcs.st-andrews.ac.uk/history/Mathematicians/Avicenna.html> [Accessed 26 July 2001]

8. Rowbotham GF: A historical survey of the treatment of injuries to the head. Neurol Neurocir Psiquiatr 11:19-29, 1970

9. Schipperges H: Eine "Summa Medicinae" bei Avicenna. Zur Krankheitslehre und Heilkunde des Ibn Sina (980-1037). Berlin: Springer-Verlag, 1987, pp 24-34

10. Schipperges H: Eine "Summa Medicinae" bei Avicenna. Zur Krankheitslehre und Heilkunde des Ibn Sina (980-1037). Berlin: Springer-Verlag, 1987, p 42

11. Stone JL, Miles ML: Skull trephanation among the early Indians of Canada and the United States. Neurosurgery 26: 1015-1020, 1990

12. Velasco-Suarez M, Bautista Martinez J, Garcia Oliveros R, et al: Archaeological origins of cranial surgery: trephination in Mexico. Neurosurgery 31:313-318, 1992

Manuscript received June 19, 2001.

Accepted in final form July 26, 2001.

Address reprint requests to: Asita S. Sarrafzadeh, Department of Neurosurgery, Charité, Virchow Medical Center, Humboldt University of Berlin, Augustenburger Platz 1, 13353 Berlin, Germany. email: asita.sarrafzadeh@charite.de. 